\title{
PEMBUKAAN UUD 1945: ANALISIS NILAI POLITIK DAN NILAI HUKUM INDONESIA
}

\author{
PREAMBLE TO THE 1945 CONSTITUTION: ANALYSIS OF \\ POLITICAL VALUES AND VALUES OF INDONESIAN LAW \\ Zulfirman \\ Universitas Pembinaan Masyarakat Indonesia \\ e-mail : zulfirman13@yahoo.com
}

Ridho Syahputra Manurung

Universitas Pembinaan Masyarakat Indonesia

e-mail : doktorridho80@gmail.com

Naskah diterima : 02/04/2018; direvisi : 15/04/2018; disetujui : 27/04/2018

\begin{abstract}
The Preamble of the 1945 Constitution as a source of reference and inspiration for the political and legal activities of the Indonesian nation. It is a hard core to organize the state of Indonesia, everything comes and comes back to it. This article discusses the values contained in it, First, the instrumental value as a political value of the value of freedom, peace and justice. Second, the intrinsic value as the legal value of religious values, humanity, unity, deliberation and justice. The essence of the value of the Preamble to the 1945 Constitution in politics is how to treat humans as human beings in common life, in the field of law how man should be treated as human in accordance with his dignity by the state. For that for the organizers of state power in carrying out their duties and functions are required to live the instrumental and intrinsic values as the basis of moral and intellectual.
\end{abstract}

\section{Keywords: Preamble of the 1945 Constitution, political value, legal value}

\begin{abstract}
Abstrak
Pembukaan UUD 1945 sebagai sumber acuan dan inspirasi kegiatan politik dan hukum bangsa Indonesia. Ia merupakan hard core untuk menata ketatanegaraan Indonesia, segala sesuatunya berasal dan kembali kepadanya. Artikel ini membahas nilai-nilai yang terkadung didalamnya, Pertama, nilai instrumental sebagai nilai politik yaitu nilai kebebasan, perdamaian dan keadilan. Kedua, nilai intrinsik sebagai nilai hukum yaitu nilai religi, kemanusiaan, persatuan, musyawarah dan keadilan. Esensi nilai Pembukaan UUD 1945 di bidang politik adalah bagaimana memperlakukan manusia sebagai manusia dalam kehidupan bersama, di bidang hukum bagaimana seharusnya manusia diperlakukan sebagai manusia sesuai dengan martabatnya oleh negara. Untuk itu bagi penyelenggara kekuasaan negara dalam menjalankan tugas dan fungsinya dipersyaratkan menghayati nilai instrumental dan intrinsik sebagai landasan moral dan intelektualitasnya.
\end{abstract}

Kata kunci: Pembukaan UUD 1945, nilai politik, nilai hukum. 


\section{PENDAHULUAN}

Dalam sejarah ketatanegaran Indonesia ada beberapa konstitusi yang pernah berlaku, yaitu: UUD 1945, UUD RIS 1949, UUDS 1950; sekarang ini yang berlaku adalah UUD 1945 yang diamandemen. Masing-masing konstitusi tersebut lahir dipengaruhi oleh suasana kebathinan dan nuansa politik yang dihadapi bangsa Indonesia yang terjadi pada masanya. ${ }^{1}$

Konstitusi atau UUD merupakan hukum dasar yang dijadikan pegangan dalam penyelenggaraan suatu negara. Konstitusi dapat pula difungsikan sebagai sarana kontrol politik, sosial dan/ atau ekonomi, dan sebagai sarana perakayasaan politik, sosial dan/atau ekonomi menuju masa depan. ${ }^{2}$ Ia merupakan ungkapan aspirasi, cita-cita, dan standar moral yang dijunjung tinggi suatu bangsa. Ia mencerminkan dasar-dasar negara serta ideologinya. Sering unsur ideologi dan moralitas itu dituangkan dalam mukadimah atau pembukaan suatu UUD. ${ }^{3}$

Dalam konteks Indonesia setidaknya hal itu dapat ditangkap dari pandangan

UUD 1945 dilahirkan pada situasi perjuangan politik melawan penjajah dan keinginan bangsa Indonesia untuk menjalankan dan mengisi kemerdekaan yang baru diraih waktu itu iklim politik yang menonjol pada waktu itu rasa kebangsaan dan persatuan mewarnai pikiran dan suasana kebathinan bangsa Indonesia waktu itu. UUD RIS 1949 lahir dipengaruhi oleh situasi politik perundingan Indonesia dengan Belanda pada Konfrensi Meja Bundar yang diadakan pada tanggal 23 Agustus sampai dengan 2 November 1949 di Den Haag dengan terpaksa Indonesia menerima bentuk Negara Republik Serikat atau federalisme. UUDS 1950 lahir akibat banyaknya rakyat negara bagian mengadakan perlawanan, akhirnya negara bagian menyatakan bergabung dengan Republik Indonesia untuk membentuk kembali Negara Kesatuan Republik Indonesia sebagai kelanjutan negara kesatuan yang diproklamasikan pada tanggal 17 Agustus 1945. Kesepakatan bersama ditandatangani oleh Pemerintah Republik Indonesia dengan Parlemen Republik Indonesia Serikat dituangkan dalam satu naskah persetujuan bersama tanggal 19 Mei 1950. Amandeman UUD 1945 lahir atas dasar tuntutan masyarakat reaksi atas tindakan otoriter penguasa yang melemahkan sivil society.

2 Jimly Asshiddiqie, Konstitusi \&Konstitusionalisme Indonesia, Jakarta: Mahkamah Konstitusi RI berkerjasama dengan Pusat Studi Hukum Tata Negara FH Univ. Indonesia, 2004, hlm. 27

3 Miriam Budiardjo, Dasar-Dasar Ilmu Politik, (Jakarta: Gramedia Pustaka Utama, 2013), hlm. 171. para pendiri bangsa pada rapat Badan Persiapan Usaha Kemerdekaan Indonesia saat menyusun rancangan UUD 1945 dan diperkuat lagi dari pandangan MPR RI saat melakukan amandemen UUD 1945 dari kesepakatan Panitia Ad Hoc I yang menegaskan pembukaan UUD 1945 memuat dasar filosofis dan dasar normatif ${ }^{4}$ juga mengandung staatidee Negara Kesatuan Republik Indonesia, tujuan negara serta dasar negara yang harus dipertahankan. ${ }^{5}$

Dari beberapa pembukaan konstitusi yang pernah ada dalam konstitusi negara Indonesia, Pembukaan UUD 1945 mempunyai sejarah tersendiri dalam pembentukannya pada Rapat Besar Badan Persiapan Usaha-Usaha Kemerdekaan Indonesia (BPUPKI) tanggal 18 Agustus 1945. Dalam rapat itu terdapat perbedaan pandangan antara golongan Islam dengan golongan nasional terkait soal agama dan soal negara ${ }^{6}$ yang ditandai pro dan kontrak atas kelimat "dengan kewajiban menjalankan syariat Islam bagi pemelukpemeluknya" yang semula termuat dalam naskah Piagam Jakarta yang akan dijadikan pembukaan UUD 1945. Perbedaan pandangan itu kembali muncul pada Sidang Konstituante pada tahun 1956 sampai tahun 1959 dalam membentuk UUD menggantikan UUDS 1950. Perbedaan pendapat dapat dimaklumi karena pembukaan suatu konstitusi berisikan ideologi yang merupakan unsur

${ }^{4}$ A.B. Kusuma menyebutnya dengan istilah staat fundamental norm. A.B. Kusuma, Lahirnya Undang-Undang Dasar 1945 Memuat Salinan Dokumen Otentik Badan Oentoek Menyelidiki Oesaha2 Persiapan Kemerdekaan, (Jakarta: Fakultas Hukum Universitas Indonesia, 2004), hlm. 355

${ }^{5}$ MPR, Panduan Pemasyarakatan Undang-Undang Dsar Negera Republik Indonesia Tahun 194 Dan Ketetapan Majelis Permusyawaratan Rakyat Republik Indonesia, Jakarta: Sekretariat Jendral MPR RI, 2012, h.18. Lihat juga A.B. Kusuma, op.cit., h. 357: Pernyataan Soepomo dalam Rapat Besar BPUPKI yang mengatakan :" "Marilah kita menginsafkan diri dahulu apakah cita-cita dan pokok-pokok pikiran yang terkandung di dalam pembukaan itu, oleh karena atas cita-cita dan pokok itu undang-undang dasar harus dibentuk".

${ }^{6}$ PT Cipta Adi Pustaka, Ensiklopedi Nasional Indonesia, jilid 13, Jakarta: Cipta Adi Pustaka, 1990, hlm. 220 
esensial bidang politik dan hukum bagi suatu negara. Masing-masing pihak ingin ideologi yang diyakininyalah yang harus dituangkan di dalam pembukaan UUD yang akan dibentuk itu.

Dari apa yang diterangkan di atas menjadi persoalan mendalam perlu dikaji adalah nilai -nilai apa yang terkandung dalam Pembukaan UUD 1945 yang dijadikan landasan politik dan hukum bagi negara Indonesia merdeka, sehingga Pembukaan UUD 1945 harus dipertahankan dalam melakukan amandeman UUD 1945 untuk menyahuti kebutuhan ketatanegaraan Indonesia sesuai dengan kehidupan politik modern dewasa ini. Artikel ini berusaha menjawab persoalan itu dengan mengeksplorasi nilainilai yang ada dalam Pembukaan UUD 1945 melalui pendekatan filsafat dan sejarah perpolitikan bangsa Indonesia.

\section{PEMBAHASAN}

\section{Isi Pembukaan UUD 1945}

Pembukaan UUD 1945 pada dasarnya adalah Piagam Jakarta suatu piagam atau naskahyang disusun oleh Panitia Sembilan ${ }^{7}$ pada tanggal 22 Juni $1945 .{ }^{8}$ Piagam Jakarta atau Jakarta Charter adalah nama yang diberikan Mr Muhammad Yamin ${ }^{9}$ atas

${ }^{7}$ Panitia Sembilan terdiri dari Drs. Mohammad Hatta, Mr. Moehammad Yamin, Mr. Achmad Soebardjo, Mr. A.A. Maramis, Ir. Soekarno, K.H. Abdoel Kahar Moezakir, K.H Wahid Hasjim, Abidkoesno Tjokrosoejoso, dan H. Agus Salim. Djon Pakan, kembali Kejatidiri Bangsa Indonesia, Sumpah Pemuda, proklamasi 17 Agustus 1945, Pancasila, Undang Undang Dasar 1945, Jakarta: Millenium Publisher, 2002, h. 144. Lihat juga A.B. Kusumo, op.cit., hlm. 213.

${ }^{8}$ Kegiatan penyusunan mukaddimah (Piagam Jakarta) dilakukan di luar prosedur yang ditetapkan yang telah ditetapkan oleh Penguasa Jepang sehingga Yosio Ichibangase menyatakan bahwa kegiatan itu adalah suatu pelanggaran. Hal itu diakui Soekarno dalam sidang BPUPKI tanggal 10 Juli 1945 sadar sama sekali, bahwa jalannya pekerjaan kami usulkan itu sebenarnya menyimpang daripada formaliteit, menyimpang dari aturan formeel yang telah diputuskan, telah ditentukan. Panitia Kecil berpendapat, jikalau formaliteit tidak sesuai dengan dinamikanya sejarah harus dirobah formaliteit itu; harus diganti formaliteit itu, harus dibongkar formaliteit itu."A.B. Kusuma, op.cit., hlm. 211.

9 Ibid., h. 329. Lihat laporan Ir Soekarno selaku panita perancang pernyatan kemerdekaan (declaration sebuah kesepakatan yang berisi tentang teks tertulis yang isinya memuat rumusan dari hukum dasar negara RI. Naskah ini semula dimaksudkan sebagai pernyataan Indonesia merdeka, ${ }^{10}$ namun akhirnya dijadikan Pembukaan atau Mukadimah dalam UUD 1945.

Piagam Jakarta berisi garis-garis pemberontakan melawan imperialismekapitalisme dan fasisme, serta memulai dasar pembentukan Negara Republik Indonesia. Secara redaksional isi Piagam Jakarta dibacakan Ir. Soekarno selaku Ketua Panitia Sembilan sebagai laporan pada Rapat Besar BPUPKI tanggal 10 Juli 1945 di Gedung Tyuoo Sangi In, berbunyi ${ }^{11}$ :

"Bahwa sesungguhnya kemerdekaan itu ialah hak segala bangsa, dan oleh sebab itu maka penjajahan di atas dunia harus dihapuskan, karena tidak sesui dengan perikemanusiaan dan peri-keadilan.

Dan perjuangan pergerakan Kemerdekaan Indonesia telah sampailah kepada saat yang berbahagia dengan selamat sentosa mengantar Rakyat Indonesia ke depan pintu gerbang Negara Indonesia, yang merdeka, bersatu, berdaulat, adil dan makmur.

Atas berkat Rahmat Allah Yang Maha Kuasa, dan dengan didorong oleh keinginan yang luhur, supaya berkehidupan kebangsaan yang bebas, maka Rakyat Indonesia menyatakan kemerdekaannya.

Kemudian daripada itu, untuk membentuk suatu Pemerintah Negara Indonesia yang melindungi segenap Bangsa Indonesia dan seluruh tumpah darah Indonesia, dan untuk memajukan

of independence) pada Rapat Besar BPUPKI tanggal 14 Juli 1945.

${ }^{10}$ Ibid., h. 324. Lihat juga Repulika.co.id, Pancasila, Sukarno, Piagam Jakarta, dan Debat Dasar Negara, 21 Sya'ban 1438 H/17 May 2017, diunduh 17 May 2017.

${ }^{11}$ A.B. Kusuma, op.cit., h. 213. Lihat juga S.Silalahi, Dasar-dasar Indonesia Merdeka versi Para Pendiri Negara, Jakarta: Gramedia Pustaka Utama, 2001, hlm. 171172. 
kesejahteraan umum, mencerdaskan kehidupan bangsa, dan ikut melaksanakan ketertiban dunia yang berdasarkan kemerdekaan, perdamaian abadi dan keadilan sosial, maka disusunlah kemerdekaan Kebangsaan Indonesia itu dalam suatu Hukum Dasar Negara Indonesia, yang terbentuk dalam suatu susunan negara Republik Indonesia yang berkedaulatan Rakyat, dengan berdasarkan kepada Ketuhanan, dengan kewajiban menjalankan syariat Islam bagi pemeluk-pemeluknya, Kemanusiaan yang adil dan beradab, Persatuan Indonesia, Karakyatan yang dipimpin oleh hikmat, kebijaksanaan dalam permusjawaratan/ perwakilan, Keadilan sosial bagi seluruh Rakyat Indonesia."

Naskah ini semula dimaksudkan sebagai pernyataan Indonesia merdeka ${ }^{12}$. Pada saat penyusunan UUD dalam sidang kedua BPUPKI, Piagam Jakarta dijadikan Mukaddimah, selanjutnya pada pengesahan UUD 1945 tanggal 18 Agustus 1945, istilah Muqaddimah dirobah menjadi Pembukaan dalam UUD $1945^{13}$; frasa "dengan kewajiban menjalankan syariat Islam bagi pemeluk-pemeluknya" dirobah menjadi Ketuhanan Yang Maha $\mathrm{Esa}^{14}$.

Piagam Jakarta yang disepakati menjadi Pembukaan UUD 1945 isinya mengandung cita-cita luhur dan pokokpokok pikiran tentang dasar dan tentang sifat-sifat negara Indonesia, atau dalam bahasa tehnis berisikan arah dan tujuan bernegara serta memuat pula lima rumusan dasar negara (Pancasila), dan ia menjiwai

${ }^{12}$ Ibid., h. 324. Lihat juga Repulika.co.id, Pancasila, Sukarno, Piagam Jakarta, dan Debat Dasar Negara, 21 Sya'ban 1438 H/17 May 2017, tanggal 17 May 2017.

${ }^{13}$ Djon Pakan, op.cit., h. 204. Lihat juga A.B.Kusuma, op.cit., h. 472. Lihat lagi S.Silalahi, op.cit., hlm. 173.

${ }^{14}$ Perubahan dilakukan oleh Drs. Mohd. Hatta atas usul A.A.Maramis setelah berkonsultasi dengan Teungku Muhammad Hassan, Kasman Singodimedjo dan Ki Bagus Hadikusumo yang semula dikatakan Ketuhanan atas usul Ki Bagus Hadikusumo menjadi Ketuhanan Yang Maha Esa. S.Silalahi, loc.cit., h. 173, lihat juga Republika.co.id. loc.cit. dan satu rangkaian kesatuan dengan UUD $1945 .{ }^{15}$ Esensinya ia mengandung nilai-nilai yang menjadi acuan dan dasar motivasi penguasa negara menjalankan ketatatanegaraan Indonesia merdeka untuk menggapai kebaikan tertinggi (summum bonum) dalam bernegara dan berbangsa.

\section{Nilai Politik dalam Pembukaan UUD 1945}

Pembukaan UUD 1945 mengandung nilai-nilai yang diyakini bangsa Indonesia yakni nilai-nilai yang berkaitan dengan politik dan nilai-nilai yang berkaitan dengan hukum. Nilai bila dilihat dari bentuknya, nilai terdiri dari dua bentuk yaitu: nilai instrumental dan nilai instrinsik. Louis O. Kattsof menyebutkan nilai instrumental adalah nilai dari sesuatu karena dapat dipakai sebagai sarana untuk mencapai tujuan tertentu, sedangkan nilai instrinsik adalah nilai dari sesuatu yang sejak semula sudah bernilai. ${ }^{16}$

Pada umumnya nilai instrumental berkaitan dengan politik sedangkan nilai instrinsik terkait dengan hukum. Nilainilai itu adalah objek tindakan yang menghargai sesuatu yang dibutuhkan, oleh karenanya, hanya mereka yang memiliki sarana untuk bertindak menuju satu tujuan tersebut ${ }^{17}$.

Nilai politik sebagai nilai instrumental pada Pembukaan UUD 1945 berbicara tentang nilai yang dijadikan dasar

${ }^{15}$ Lihat pernyataan pernyataan Soepomo dalam Rapat Besar BPUPKI tanggal 15 Juli 1945 yang mengatakan "Dengan menerimanya pembukaan tersebut kita tidak bisa bertindaklain dari pada membentuk undang-undang dasar yang berdasarkan atas aliran pikiran yang termasuk dalam pembukaan ini. A.B. Kusuma, op.cit., h. 357, dipertegas lagi oleh Dekrit Presiden 5 Juli 1959, dan Memorendum DPRGR 1966 mengenai sumber tertib hukum RI ditingkatkan menjadi keputusan MPRS Nomor XX/MPRS/1966.

16 Darji Darmodiharjo dan Shidarta, PokokPokok Filsafat Hukum Apa dan Bagaimana Filsafat Hukum Indonesia, (Jakarta: Gramedia Pustaka Utama, 2002), hlm. 234.

${ }^{17}$ Craig Biddle, "Any Rand's Theory of Rights : The Moral Foundation of a Free Society", The Objective Standard, Glen Allen Press, Vol. 6, No. 3 (2011), hlm. 66. 
penyelenggaraan pemerintahan dalam konteks identitas bersama ${ }^{18}$. Esensinya bagaimana penguasa memperlakukan manusia sebagai manusia dalam ikatan identitas bersama yang menjadi dasar bagi kegiatan politik agar kehidupan manusia menjadi lebih baik, sejahteraan yang berkeadilan. Ia mengandung hal-hal yang normatif, bentuk-bentuk kehidupan yang baik, apa yang pantas secara moral, dan jenis keputusan yang benar. Ia mengandung nilai-nilai yang sangat diperlukan individu dalam kapasitasnya sebagai anggota dari suatu identitas bersama.

Nilai-nilai yang termuat di dalam Pembukaan UUD 1945 terkait nilai politik menjadi salah satu hal penting karena fungsi nilai yang terkandung didalamnya mengacu pada tujuan yang diiinginkan yang memotivasi tindakan, di samping itu juga berfungsi sebagai standar atau kriteria tindakan kekuasaan negara terhadap manusia yang ada demikian pula sebaliknya. Para teoriawan mengatakan nilai-nilai, norma, dan simbol-simbol ekspresif yang yang dianut bersama memberikan semacam ikatan sosial yang mempersatukan anggota-anggota masyarakat; karena orang menganut suatu perasaan identitas bersama, maka tatanan sosial menjadi mungkin ${ }^{19}$. Nilainilai itu menggambarkan apa yang baik, apa yang buruk, apa yang benar dan apa yang salah bagi semua manusia. Nilai itu sendiri adalah sesuatu yang diinginkan atau tujuan transituasional beraneka ragam kepentingan yang berfungsi sebagai prinsip panduan dalam kehidupan masyarakat. ${ }^{20}$ Ia berkaitan dengan

\footnotetext{
${ }^{18}$ Charles F. Andrain, Kehidupan Politik dan Perubahan Sosial, terjemahan Luqman Hakim, Yogyakarta: Tiara Wacana, 1992, h. 74: Identitas bersama menetapkan dasar keanggotaan dalam suatu komunitas politik, inilah masalah politik yang paling mendasar sebagai wilayah pusat (central zone) bagi masyarakat.

${ }^{19}$ Charles F Andrain, Kehidupan Politik dan Perubahan Sosial, terjemahan Luqman Hakim, Yogyakarta: Tiara Wacana, 1992, hlm. 75.

${ }^{20}$ Shalom H. Schwartz, Basic Human Values, Paper : Comparation Seminar on the Quality and Comparabili-
}

kepentingan manusia baik kepentingan itu bersifat lahiriah atau batiniah ${ }^{21}$. Pada manusia terdapat nilai dan manusia itu sendiri sebagai penyandangnya ${ }^{22}$, keberadaannya mendahului keberadaan manusia.

Nilai politik yang pertama dalam Pembukaan UUD 1945 adalah nilai kebebasan sebagaimana termuat pada frasa "kemerdekaan itu ialah hak segala bangsa". Frasa ini suatu bentuk deklaratif tentang nilai kebebasan yang bersifat esensial dan universal. Sifat esensialnya adalah kebebasan sebagai nilai bukan hasil ciptaan manusia tapi ia merupakan suatu yang mutlak tidak dikondisikan oleh suatu perbuatan tanpa memperhatikan hakikatnya, nilai itu bersifat historis, sosiologis, biologis atau murni individual. ${ }^{23}$ Kebebasan merupakan spirit yang sangat mahal harganya. Ia bukan barang dagangan yang dapat diperjual belikan. ${ }^{24}$ Sifat universalnya adalah nilai itu sangat bernilai bagi manusia dan sifatnya tidak dapat dihilangkan, oleh karenanya kebebasan nilai yang bersifat abstrak atau sebagai suatu asas. ${ }^{25}$ Apa yang disebutkan ini jelas terungkap dalam frasa "pendjadjahan di atas dunia harus dihapuskan".

Kemerdekaan adalah lambang kehormatan, martabat, dan harga diri suatu bangsa. ${ }^{26}$ Dalam kehidupa bernegara

ty of Measures for Constructs in Comparative Research: Methods and Applications, Bolzano (Bozen), Italy, June 10-13, (2009), hlm. 2.

${ }^{21}$ Amril M. Etika Islam Telaah Pemikiran Filsafat Moral Raghib Al-Isfahani, (Pekan Baru: LSFK2P bekerjasama dengan Yogyakarta: Pustaka Pelajar, 2002), hlm. 115.

${ }^{22}$ Evan J. Criddle, Evan Fox-Decent, Human Rights, Emergencies, and the Rule of Law, Human Rights Quarterly, The Johns Hopkins University Press, Vol. 34, No. 1 (2012), hlm. 45.

${ }^{23}$ Risieri Frondizi, Pengantar Filsafat Nilai, terjemahan Cuk Ananta Wijaya, Yogyakarta: Pustaka Pelajar, 2001, hlm. 115.

${ }^{24}$ Sukarna, Kekuasaan, Kediktatoran dan Demokrasi, Bandung: Alumni, 1981, hlm. 91.

${ }^{25}$ Miriam Budiarjo, Dasar-Dasar Ilmu Politik, Jakarta: Gramedia Pustaka Utama, 2013, hlm. 23.

${ }_{26}$ S. Silalahi, Dasar-dasar Indonesia Merdeka versi Para Pendiri Negara, Jakarta: Gramedia Pustaka Utama, 2001, hlm. 165. 
kata kemerdekaan menggambarkan nilai politik dan sosiologis. Konsep sosiologis kemerdekaan mengandung arti sebagai kebebasanindividudalamkonteksmakhluk sosial. Janji kemerdekaan yang termuat di dalam Pembukaan UUD 1945 adalah suatu pernyataan untuk membebaskan rakyat Indonesia seluruhnya, yakni secara kolektif merdeka sebagai bangsa dan secara orang perorangan merdeka sebagai warga negara ${ }^{27}$.

Nilai kebebasan yang terkandung dalam Pembukaan UUD 1945 berhubungan dengan manusia dalam konteks makhluk sosial sebagaimana dapat ditangkap dari frasa "tidaksesuaidenganperikemanusiaan dan perikeadilan". Kebebasan adalah salah satu syarat bagi martabat manusia. Akan tetapi kebebasan dan martabat manusia hanya merupakan gagasan kosong belaka, bilamana kedua hal itu tidak diterapkan secara nyata dalam masyarakat di mana kita hidup. Oleh karenanya, pemerkosaan terhadapnya harus dilawan dan bila dilanggar harus diperjuangkan.

Perjuangan atas kebebasan yang tercatat dalam sejarah politik bangsa Indonesia adalah perjuangan kebebasan dari berbagai bentuk penindasan, perbudakan, kesewenang-wenangan penguasa bahkan juga kebebasan dari penjajahan serta menjamin adanya perlindungan individu menghadapi absolutisme. ${ }^{28} \mathrm{Hal}$ ini jelas terlihat dari frasa "Perdjuangan pergerakan Kemerdekaan Indonesia telah sampailah kepada saat jang berbahagia dengan selamat sentosa" sebagaimana termuat pada alinea kedua Pembukaan UUD 1945. Penghapusan penjajahan, penindasan dan perlakuan sewenang-

${ }^{27}$ Adnan Buyung Nasution, Aspirasi Pemerintahan Konstitusional di Indonesia, terjemahan Sylvia Tiwon, Jakarta: Pustaka Utama Grafiti, 1995, hlm. ix.

${ }_{28}$ Hesti Armiwulan Sochmawardiah, Diskriminasi Rasial Dalam Hukum HAM, Studi Diskriminasi Terhadap Ethnis Tionghoa, Yogyakarta : Genta Publishing, 2013, h. 42. Menurut hemat penulis dalam sejarah ketetanegaraan Indonesia setelah merdeka perjuangan atas kebebasan terjadi dalam melawan pemerintahan otoriter. wenang atau perbudakan sudah terjadi cukup tua. Hal itu dapat dilihat apa yang dilakukan Cyrus Agung tahun 539 SM, raja pertama Persia kuno, yang menaklukkan kota Bebel. Penaklukan itu berikutnya menandai kemajuan besar bagi manusia. Dia membebaskan para budak, menyatakan bahwa semua orang memiliki hak untuk memilih agama mereka sendiri, dan mendirikan kesetaraan ras. ${ }^{29}$

Nilai lainnya yang berhubungan erat dengan nilai kebebasan adalah nilai persatuan dan nilai keadilan. Nilai persatuan dapat dilihat pada kata "bersatu" dan nilai keadilan terlihat pada kata "adil" dalam frasa "Negara Indonesia, yang merdeka, bersatu, berdaulat, adil dan makmur". Nilai persatuan merupakan suatu nilai objektif yang menghinggapi manusia yang memang secara fisik, budaya, bahasa, dan keyakinan berneka ragam. Keragaman manusia itu merupakan mozaik dari kehidupan sosial dan disanalah secara politik manusia disebut zoon piliticon oleh Aristoteles. Kebutuhan bersatu itu adalah kodrat manusia untuk dapat mengembangkan diri dan kualitas hidupnya demi tujuan hidup yang dicitadicitakan yakni kehidupan yang baik. Sulit dapat dipahami kehidupan manusia tanpa berhubungan dengan manusia lainnya.

Dalam kehidupan sosial, nilai keadilan memandu individu untuk memperlakukan manusia yang satu terhadap manusia lainnya dalam menjaga eksistensinya dan menjaga kehidupan sosial manusia. Hubungan manusia sarat dengan masalah keadilan membuat selalu peka untuk suatu tinjauan yang bersifat sosiologis ${ }^{30}$. Masalah adil dan tidak adil hanya dapat muncul akibat rangkaian aksi dan reaksi dalam kompleks perilaku manusia yang ko-oksistensial.

\footnotetext{
${ }^{29} \mathrm{http}: / /$ www.humanrights.com/what-are-humanrights/brief-history/syrus-cylinder.html, diunduh 13 April 2017.

${ }^{30}$ Budiono Kusumohamidjojo, Filsafat Hukum, Problematik Ketertiban yang Adil, Jakarta: Grasindo, 2004, h, 182.
} 
Hakikat keadilan terletak pada tidak melakukan perbuatan zalim. Perbuatan zalim yang dasariah adalah eksploitasi, perbudakan atau mengambil keuntungan dari hidup orang lain. ${ }^{31}$ Dalam konteks negara Indonesia Mohd Hatta pernah berkata tiap-tiap manusia dalam masyarakat diperlakukan sama oleh negara dalam segala rupa dan bebas dari tindakan kezaliman. ${ }^{32}$ Keadilan adalah suatu proses yang melalui proses itu di dalam masyarakat, selaras dengan nilai-nilai moral dan sosial, yang dapat menghilangkan eksplotasi, penindasan dan kezaliman. ${ }^{33}$

Selain nilai yang disebutkan di atas, nilai politik lainnya yang terkandung dalam Pembukaan UUD 1945 adalah nilai religi sebagai pengikat nilai-nilai lainnya. Hal itu dapat dilihat pada frasa "Atas berkat rahmat Tuhan Yang Maha Esa" pada alinea ketiga Pembukaan UUD 1945. Nilai religi ini merupakan sila kelima $^{34}$ dasar negara yang diusulkan Soekarno dalam Rapat BPUPKI tanggal 1 Juni 1945. Soekarno berpendapat nilai religius ini, dilihat hirarki nilai, berada pada posisi teratas dibanding nilai-nilai lainnya. Hemat penulis, penempatan nilai religi (Ketuhanan) sebagai sila kelima dari Pancasila dalam usulan Soekarno waktu itu tidaklah dimaksudkan nilai tersebut berkedudukan lebih rendah dari nilai kebebasan, persatuan dan keadilan. Hal ini tegas dinyatakan Soekarno dari pernyataannya "Negara kita ialah Ketuhanan yang berkebudayaan, Ketuhananyangberbudipekertiyangluhur, Ketuhanan yang hormat-menghormati satu sama lain. Hatiku akan berpesta

\footnotetext{
${ }^{31}$ Karen Leback, Teori-Teori Keadilan, terjemahan Yudi Santoso, Bandung: Nusa Media, 2015, hlm. 160.

32 Anwar Abbas, Bung Hatta \& Ekonomi Islam, Pergulaan Menangkap Makna Keadilan dan Kesejahteraan, Jakarta: Kerjasama LP3M, Fakultas Hukum Universitas Muhamadyah dan Multi Pressindo,2008, hlm. 179.

${ }^{33}$ Ziauddin Sardar dan Marryl Way Davies, Wajah Islam, Bandung: Mizan, 1992, hlm. 59.

${ }^{34}$ Sila pertama kebangsaan, sila kedua internasionalisme atau perikemanusiaan, sila ketiga Mufakat atau demokrasi, sila keempat Kesejahteraan sosial.
}

raya, jikalau Saudara-saudara menyetujui bahwa Negara Indonesia berasaskan Ketuhanan Yang Maha Esa". Terkait nilai religius ini lebih lanjut Soerkarno mengatakan "Ingatlah, prinsip ketiga, permufakatan, perwakilan, di situlah tempatnya kita mempropagandakan ide kita masing-masing dengan cara yang tidak overdraagzaam, yaitu dengan cara yang berbudaya" 35 .

Agama yang menambahkan sesuatu yang sangat penting kepada substansi manusia, dan jika ini ditolak atau diabaikan tampaknya akan menghasilkan akibat melumpuhkan pada kehidupan manusia. Tanpa pemujaan manusia menyusut. Jika Anda tidak memuja apa pun Anda bukan apa-apa. Agamaagama tradisional telah mengungkapkan dengan jelas struktur-struktur kebutuhan manusia untuk memuja hal-hal ideal yang lebih besar dripada dirinya sendiri. Fungsi utama struktur-sgruktur religius adalah memberikan suatu kerangka kerja bagi hal-hal ideal yang sedang mengilhami dan menopang kehidupan manusia. Agamaagama tradisional telah mengungkapkan dengan jelas struktur-struktur kebutuhan manusia untuk memuja hal-hal ideal yang lebih besar dari pada dirinya sendiri. Fungsi utama struktur-struktur religius adalah memberikan suatu kerangka kerja bagi hal-hal ideal yang sedang mengilhami dan menopang kehidupan kita. ${ }^{36}$

Dalam sejarah kebangsaan Indonesia membuktikan, nilai religi sebagai nilai

\footnotetext{
35 Wawan Tunggul Alam (ed), Bung Karno
} Menggali Pancasila, Kumpulan Pidato, Jakarta: Gramedia Pustaka Utama, 2001, h. 29. Lihat juga A.B. Kusuma, op.cit., h. 163. Hemat penulis, cara berpikir Soekarno dalam mengusulkan nilai-nilai dasar negara Indonesia merdeka beranjak dari dunia konkrit (nyata) yaitu fakta bangsa Indonesia ke dunia abstrak (ideal) yaitu dunia cita-cita bangsa Indonesia. Cara berpikir demikian dalam dunia akademis dikenal dengan metode berpikir induktif ke deduktif. Jadi, tidak bijaksana bila ada pendapat yang mengatakan Pancasila yang diusulkan Soekarno menempatkan nilai Ketuhanan pada posisi yang rendah.

${ }^{36}$ Hanryk Skolimowski, Eco-Philosophy: Designing New Tactics for Living, terjemahan Saut Pasaribu, Yogyakarta: Bentang, 2004, hlm. 146). 
tertinggi sudah mengurat akar dalam perpolitikan kerajaan di nusantara waktu itu, hal ini ditandai nilai religius telah memberi warna pada sifat dan karakter kerajaan nusantara waktu itu. ${ }^{37}$ Nilai religi termuat di dalam ajaran agama yang menambahkan sesuatu yang sangat penting kepada substansi manusia, dan jika ini ditolak atau diabaikan tampaknya akan menghasilkan akibat melumpuhkan pada kehidupan manusia; ini sebagai landasan moral bagi penyelenggara kekuasaan negara dalam memandang dan memperlakukan manusia dalam kehidupan bersama.

Secara teoritis, posisi nilai religius sebagai nilai tertinggi dapat dipahami bila dikaitkan dengan nilai kebebasan. Kebebasan hanya dapat dipahami terkait dengan perciptaan Tuhan. Masalah penciptaan benar-benar masalah kebebasan. Kajian kebebasan manusia dapat dipahami melalui pemahaman tentang manusia sebagai ciptaan Tuhan merupakan kajian yang cukup tua. ${ }^{38}$ Abraham Lincoln tidak ragu-ragu untuk menegaskan bahwa kebebasan memerlukan kepercayaan pada Tuhan. ${ }^{39}$ Dalam bahasa yang lain tapi dengan makna sama Izetbegovic mengatakan jika seseorang memberikan atribut kebebasan kepada manusia, jika ia menganggap manusia mempunyai beban tanggungjawab, maka ia akan melihat eksistensi Tuhan, baik secara diam-diam maupun secara terbuka. Hanya Tuhan yang mampu untuk menciptakan makhluk

${ }^{37}$ Misalnya kerajaan Sriwijaya dan Syailendera adalah kerajaan Budha, Kutai dan Majapahit kerajaan Hindu; Samudra Pasai, Demak, kesultanan Bone dan Gowa, kesultanan Ternate, Tidore, Sultan Iskandar Muda kerajaan Islam.

${ }^{38}$ Raja Cyrus Agung pada tahun 539 SM misalnya memberi kebebasan bagi rakyatnya untuk memilih agama mereka sendiri, Yunani Kuno misalnya kepercayaan pada dewa-dewa dan Raja sebagai wakil Tuhan di dunia dalam kancah perpolitikan masa itu dan masa sesudahnya berkembang dalam kajian kenegaraan.

${ }^{39}$ Francis Fukuyama, Memperkuat Negara Tata Pemerintahan dan Tata Dunia abad 21, terjemahan A. Zaim Rofiqi, Jakarta: Gramedia Pustaka Utama 2005, hlm. 571. bebas, dan kebebasan hanya timbul dari tindakan penciptaan ${ }^{40}$.

Nilai kebebasan, persatuan, keadilan sebagai nilai instrumental atau nilai politik. Nilai itu adalah objek tindakan yang menghargai sesuatu yang dibutuhkan, oleh karenanya, hanya mereka yang memiliki sarana untuk betindak menuju satu tujuan tersebut ${ }^{41}$. Sarana untuk menegakan nilai-nilai tersebut adalah pemerintah. Hal ini tegas dinyatakan dalam alinea keempat Pembukaan UUD 1945 pada frasa "“membentuk suatu Pemerintah Negara Indonesia yang melindungi segenap Bangsa Indonesia dan seluruh tumpah darah Indonesia, dan untuk memajukan kesejahteraan umum, mencerdaskan kehidupan bangsa, dan ikut melaksanakan ketertiban dunia yang berdasarkan kemerdekaan, perdamaian abadi dan keadilan sosial". Dari frasa ini dapat diambil maknanya, tujuan utama pemerintah Indonesia ada tiga hal yaitu (a) keamanan (b) keadilan, dan (c) pemeliharaan. Keamanan dalam pengertian melindungi hidup dan milik, sebagai satu tujuan pertama dari negara. Keadilan terutama ditujukan kepada keadilan ekonomi, di sini dimaksudkan persamaan. Keadilan ekonomi tidak ada jika negara tidak mengadakan campur tangan dalam lapangan industri dan keuangan. Keadilan terdapat di antara yang sama-sama miskin dan di antara mereka yang sama-sama kaya. Akan tetapi tidaklah akan ada gunanya memiskinkan

40 'Alija 'Ali Izetbegovic, Membangun Jalan Tengah Islam antara Timur dan Barat, terjemahan Nurul Agustina, Farid Gaban, Bandung: Mizan, 1992, hlm. 64. Lihat juga dalam ajaran Islam, Al Qur'an surat Yaa siin ayat (82) yang artinya "Adapun urusannya, bila Ia berkehendak akan mengadakan sesuatu, Ia berkata baginya : KUN (jadilah), maka terjadilah ia"; Surat A1 Bakarah ayat (3) yang artinya "Dan ingatlah ketika Tuhanmu berfirman kepada malaikat, Aku akan mengangkat Adam menjadi khalifah di muka bumi;" Surat Al An'am ayat (165) yang artinya "Dan Dia-lah yang menjadikanmu Penguasa di bumi..." Surat A1 Fathir ayat (39) yang artinya "Dia-lah yang menjadikan kamu khalifah di muka bumi...".

${ }^{41}$ Craig Biddle, "Any Rand's Theory of Rights : The Moral Foundation of a Free Society", The Objective Standard, Glen Allen Press, Vol. 6, No. 3, 2011, hlm. 66. 
orang yang kaya, kalau tidak akan dapat mengerjakan orang yang miskin. Pemeliharaan memelihara sumbersumber alam adalah suatu hal yang amat penting. Karena sumber daya alam pada prinsipnya terbatas dan ada yang tidak dapat diperbaharui.

Dari uraian di atas dapat disarikan, Pembukaan UUD 1945 mengandung nilai politik dalam bentuk nilai instrumental yakni nilai kebebasan, nilai persatuan, dan nilai keadilan yang diformalkan dalam bahasa tehnis sebagai kemerdekaan, perdamaian dan keadilan sosial. Semua nilai itu diikat oleh nilai religius sebagai moral umum dan moral individu. Landasan moral ini menjadi penting, karena kalau moral umum tidak ada, maka persekutuan hidup akan binasa; kalau moral pribadi tidak ada, maka persekutuan hidup tidak akan ada harganya ${ }^{42}$. Dari sanalah akan tercapai kebaikan tertinggi (summum bonum) dalam bernegara dan berbangsa.

\section{Nilai Hukum dalam Pembukaan UUD 1945}

Pada kesempatan di atas telah dianalisis nilai politik sebagai nilai instrumental yang menjadi dasar motivasi pemerintah dalam menyelenggarakan kegiatannya dalam mewujudkan keamanan, keadilan dan pemeliharaan negara Indonesia. Dalam rangka melaksanakan tugas tersebut kegiatan politik harus dikawal dan berpedoman pada nilai instrinsik dari nilai hukum. Pada posisi yang demikian itulah terlihat hubungan hukum dengan politik. Tugas politik modern adalah menjinakkan kekuasaan negara, mengarahkan kegiatan-kegiatannya ke arah tujuan-tujuan yang dianggap sah oleh rakyat yang dilayaninya, dan menjalankan kekuasaan di bawah aturan hukum ${ }^{43}$.

${ }^{42}$ Bertand Russel, Kekuasaan dan Individu, terjemahan Kamaruzzaman, Jakarta: Yayasan Pembangunan, 1953, hlm. 110.

${ }^{43}$ Francis Fukuyama, Memperkuat Negara Tata Pemerintahan dan Tata Dunia abad 21, terjemahan A. Zaim Rofiqi, Jakarta: Gramedia Pustaka Utama 2005, hlm. 2 .

80 IUS Kajian Hukum dan Keadilan
Tugas politik modern bagi bangsa Indonesia termuat dalam Pembukaan UUD 1945 pada frasa "disusunlah kemerdekaan Kebangsaan Indonesia itu dalam suatu Hukum Dasar Negara Indonesia". Frasa ini menjelaskan tentang kekuasaan negara diselenggarakan di bawah hukum. Kekuasaan negara dijalankan atas dasar tujuan yang sah menurut rakyat. Tujuan yang sah itu menurut Pembukaan UUD 1945 adalah yang termuat pada alinea keempat dalam frasa "berdasarkan kepada Ketuhanan Yang Maha Esa, Kemanusiaan yang adildanberadab, Persatuan Indonesia, Karakyatan yang dipimpin oleh hikmat, kebijaksanaan dalam permusjawaratan/ perwakilan, Keadilan sosial bagi seluruh Rakyat Indonesia." Kelima hal itu merupakan nilai instrinsik yang harus menjadi acuan dalam membentuk hukum juga kebijakan yang berkaitan dengannya. Ia merupakan sistem nilai-nilai, citacita yang harus diterjemahkan ke dalam produk-produk hukum. ${ }^{44}$ Nilai instrinsik tersebut pada umumnya stabil, bukannya berubah-ubah. Dari sanalah dapat diketahui adanya keterkaitan politik dan hukum bagi bangsa Indonesia.

Bila dicermati secara mendalam, nilai instrinsik dari lima dasar negara Indonesia pada dasarnya berhubungan dengan konsep manusia sebagai makhluk religius, makhluk sosial dan makhluk posesif $^{45}$. Konsep manusia sebagai makhluk religius terdapat pada frasa "KetuhananYang Maha Esa" dan frasa "Perikemanusiaan yang adil dan beradab". Konsep manusia sebagai mahluk sosial pada frasa "Persatuan Indonesia" dan frasa "Kerakyatan yang dipimpin oleh hikmah

${ }^{44}$ I Dewa Gede Atmadja, Ilmu Negara, Sejarah, Konsep Negara dan Kajian Kenegaraan, Malang: Setara Press, 2012, hlm. 61.

${ }^{45}$ W. Poespoprodjo, Filsafat Moral, Kesusilaan dan Teori dan Praktek, Bandung: Remaja Karya, 1986, hlm. 126. Bandingkan dengan Ade Armanto (ed), Ensiklopedi Islam Untuk Pelajar, Jakarta: Ichtiar Van Hoeve, 2001, h. 21: Al Qur'an istilah manusia disebut dengan tiga istilah : al-Insan, manusia dalam hubungannya dengan Tuhan; an-nas, manusia makhluk sosial dan; al-basyar manusia makhluk biologis. 
kebijaksanaan dalam permusyawaratan/ perwakilan. Konsep manusia sebagai makhluk posesif atau biologis yang pada frasa "Keadilan Sosial bagi seluruh Rakyat Indonesia". Apa yang disebutkan terakhir ini berhubungan dengan kehidupan ekonomi dan kesejahteraan manusia. Tiga hal konsep manusia itu pada intinya berbicara tentang hubungan manusia dengan Tuhan, sesama manusia dan dengan alam. Hubungan ketiganya merupakan keniscayaan, dan dari sanalah dibangun sistem hukum Indonesia.

Lima dasar negara yang mengandung nilai isntrinsik pada Pembukaan UUD 1945 merupakan nilai hukum yang berhubungan dengan tiga hal yaitu (a) karakter hukum positif Indonesia (b) pembuatan hukum positif Indonesia, dan (c) substansi hukum positif Indonesia. Nilai instrinsik tersebut sebagai dasar motivasi bertindak untuk mewujudkan cita-cita hidup bersama bagaimana memperlakukan manusia sebagai manusia sesuai dengan kemanusiaannya.

Salah satu ciri khas nilai yang hakiki adalah penampakannya dalam urutan hirrarki. Nilai itu tersusun dalam sebuah hubungan hirarki a priori. Hirarki baginya harus ditemuka di dalam hakinat nilai itu sendiri bahkan itu juga berlaku bagi ilia yang tidak diketahui. Ada lima kriteria nilai. Pertama, keabadian nilai, benda yang lebih abadi akan lebih disukai dari pada yang bersifat sementara. Kedua, sifat yang dapat dibagi-bagi, Ketinggian yang dicapai nilai berbanding terbalik dengan sifat dapat dibagi-baginya, yakni semakin tinggi derajatnya, semakin kecil sifat untuk dapat dibagi-bagi. Ketiga, jika satu nilai menjadi dasar bagi nilai yang lain, nilai tersebut lebih tinggi daripada nilai yang lain. Keempat, nilai yang tertinggai menghasilkan kepuasan yang terdalam. Kelima, nilai yang tertinggi adalah nilai keagamaan. ${ }^{46}$

\footnotetext{
${ }^{46}$ Risieri Frondizi, op.cit., hlm. 132-134.
}

Nilai hukum pertama yang termuat di dalam lima dasar negara Indonenesia adalah nilai religius sebagaimana termuat pada frasa "Ketuhanan Yang Maha Esa". Nilai ini berhubungan dengan agama. Pandangan Agama tidak saja diarahkan kepada pencarian jawaban kehidupan setelah kematian, tetapi ia juga menjadi dasar bagi pengaturan kehidupan manusia didunia termasuk memberikan dasar moral bagi berbagai usaha untuk memuliakan hidup dan kehidupan manusia ${ }^{47}$. Agama berhubungan erat dengan Tuhan sebagai hal esensial dan universal sifatnya. Keberadaan Tuhan adalah kebutuhan laten manusia, kalau pun ada perbedaan tentangnya tidaklah berkenaan dengan hakikat adanya Tuhan melainkan mengenai hakikat makna Tuhan dalam pembahasan. Ketuhanan Yang Maha Esa sebagai dasar negara terfokus pada moral, yang dalam hukum berhubungan dengan keadilan yang bersifat transedenta ${ }^{48}$.

Nilai religius memiliki fungsi yang terpenting bagi pelaku kekuasaan negara tidak saja di bidang politik tapi juga bidang hukum dan ekonomi; lebihlebih lagi dalam membangun sistem hukum positif Indonesia. Nilai religius ini adalah nilai tertinggi dari nilai-nilai lainnya yang termuat di dalam lima dasar negara Indonesia. Socrates dan Nabinabi mengajarkan kepada kita, bahwa kita harus mentaati Tuhan lebih dari pada mentaati manusia. Kita mencintai Tuhan, mereka ada mempunyai paksaan hasrat batin untuk memenuhi hasrat cipta mereka dan mempunyai kegembiraan batin, apabila hal ini dilakukan. Getaran kalbu ini adalah dasar dari kewajiban terhadap Tuhan ${ }^{49}$. Nilai religi ini jelasjelas berhubungan dengan moralitas. Jadi,

\footnotetext{
${ }^{47}$ Dadang Juliantra, Jalan Kemanusiaan, Panduan Untuk Memperkuat Hak Asasi Manusia, Yogyakarta: Lapera Pustaka Utama, 1999, hlm. 29.

${ }^{48}$ Anwar Abbas, Bung Hatta dan Ekonomi Islam, Jakarta: LP3M Ahmad Dahlan bekerjasama dengan Fakultas Hukum Muhammadiyah Jakarta dan Multi Presindo, 2008, hlm. 151.

${ }^{49}$ Bertand Russel, op.cit., hlm. 118.
} 
bagi pelaku kekuasaan negara termasuk pembuat dan penegak hukum; kepintaran saja tidaklah cukup tanpa memiliki moral yang terpuji. Penerapan pengetahuan dan teknik dapat berakibat fatal apabila nilai-nilai dan ukuran moral ditolak dan diinjak-injak. Kekacuan yang timbul dari perbenturan kekuatan-kekuatan dunia, dengan segala potensinya yang ada, pemusnahan dengan tenaga atom, terjadi sebagai penderitaan manusia akibat ulahnya sendiri, karena tidak memiliki pegagangan batin dan moral. Tidaklah seseorang menjadi pembangun, jika moral mereka hancur lebur.

Nilai religius sebagai nilai hukum berhubungan dengan keberadaan manusia sebagai makluk religius. Ia berhubungan dengan martabat manusia agar hidup manusia tidak menjadi hambar. Nilai ini harus diimplementasikan pada sistem hukum dan sistem hukum yang dibangun itu diselaraskan kepada manusia bukan manusia diperas dalam sistem. Nilai itu menjadi petunjuk arah atau kompas hukum dalam membangun hukum positif Indonesia. Hukum muncul pada masa ketika terdapat keseimbangan antara aspirasi-aspirasi religius dan aspirasiaspirasi sosial politik dalam pikiran banyak orang. Itulah masa ketika rasa keagamaan makin kuat, dan masih mempengaruhi kehidupan orang-orang, tetapi juga dibatasi secara luas oleh alasanalasan utilitarian rasional dari munculnya peradaban. ${ }^{50}$

Nilai religus sebagaimana disebutkan di atas memberi warna atau karakter hukum positif Indonesia dengan visi idealitas-Spiritualitas. ${ }^{51}$ Corak hukum yang seperti ini dalam kajian filsafat hukum dikenal sebagai pemikiran hukum alam, yang oleh Cotterrel dikatakan teori hukum alam yang telah mempostulasikan

\footnotetext{
50 'Alija 'Ali Izetbegovic, op.cit., hlm. 239.

${ }^{51}$ Corak hukum yang demikian ini dapat dilihat dari pernyataan Soerkano tanggal 1 Juni 1945 dalam Sidang BPUPKI pada saat membahas sila kelima (Ketuhanan) yang mengatakan " hendaknya negara bertuhan"
}

keberadaan prinsip-prinsip moral yang memiliki validitas dan otoritas terlepas dari penetapan-penetapan hukum manusia, dan bisa dipandang sebagai hukum yang "lebih tinggi" atau lebih fundamental untuk menilai kelayakan atau otoritas hukum manusia. Dengan begitu ia tidak membutuhkan legislator manusia, sungguhpun begitu ia berkubu di dalam hukum yang diciptakan oleh para legislator ${ }^{52}$. Pada sisi lain Nelson menerangkan hukum alam formal berorientasi pada cita-cita martabat manusia, karena dirinya didapati eksistensi hak yang tidak dapat dialihkan. Tidak dapat dialihkan atau dilimpahkan ialah bahwa persetujuan atas pelanggaran kepentingan yang menentukan isi hak oleh orang yang berhak tidak membebaskan orang lain dari kewajiaban untuk menghormati kepentingan itu ${ }^{53}$.

Nilai itu harus diinsyafi, bahwa ada beberapa hal yang mempunyai nilai yang tidak ada hubungannya sedikitpun dengan gunanya. Apa yang berguna, adalah berguna, karena ia menjadi alat untuk memperoleh yang lain dan yang lain itu, walaupun tidak hendak mempunyai kegunaan, mestilah dihargai karena wujudnya sendiri, kalau tidak tentulah kegunaannya itu suatu khayalan saja. Dalam kajian filsafat nilai dituangkan dalam terminologi normatif. Ia menunjukan keutamaan nilai yaitu kebaikan tertinggi (summum bonum) tertentu. ${ }^{54}$

Nilai hukum kedua yang termuat di dalam Pembukaan UUD 1945 adalah nilai kemanusiaan, hal ini termuat pada frasa "Kemanusiaan yang adil dan beradab".

52 Werner Menski, Perbandingan Hukum dalam Konteks Global Sistem Hukum Eropa, Asia dan Afrika, terjemahan M.Kozhim, Bandung: Nusa Media, 2012, hlm.222.

${ }^{53}$ Carl Joachim Friedrich, Filsafat Hukum Persepektif Historis, terjemahan Raisul Muttaqien, Bandung: Nuasa bekerjasama dengan Nusamedia, 2004, hlm. 234.

${ }^{54}$ Bernard L. Tanya, et.al, Teori Hukum Strategi Tertib Manusia Lintas Ruang dan Generasi, Yogyakarta: Genta Publishing, 2013, hlm. 205. 
Nilai itu terkait dengan perlakuan dan kedudukan manusia dalam hukum. Ia menjadi tolok ukur seluruh sistem hukum. Marcic menegaskan pangkal hukum yang sejati ialah nilai manusia yang tidak dapat hilang ${ }^{55}$. Prinsip ini sebagai landasan keharusan agar manusia diperlakukan sebagai manusia sesuai dengan harkat dan martabat kemanusiaannya, keharusan yang demikian itu berlaku tidak saja kepada negara tetapi juga bagi setiap orang. Inti kegunaan hukum yang paling mendasar dan mendalam adalah agar keberadaan manusia terjaga dan manusia diperlakukan sebagai manusia, di sanalah kita dapat membedakan hukum manusia dibanding hukum kealaman. Hukum yang tidak memihak kepada manusia bukanlah hukum yang sejati. Dalam suatu hukum atau undang-undang tersebunyi nilainilai dan kaidah-kaidah yang membentuk wawasan orang atas manusia dan masyarakat. ${ }^{56}$

Nilai kemanusiaan sebagaimana tertuang dalam Pembukaan UUD 1945 memberikan ketegasan dan memperkuat hukum Indonesia menganut paham pemikiran hukum alam, karena hukum alam, menurut Ronal Dworkin, mengandung aspek etis dari hukum. Semua produk hukum harus menjunjung tinggi marabat manusia sebagai pribadi. Semua produk hukum harus menciptakan tatanan hukum yang menjamin keluangan manusia dapat mengembangkan dirinya secara penuh untuk menjadi manusia utuh. ${ }^{57}$

${ }_{55}$ Theo Huijbers, Filsafat Hukum, Yogyakarta: Kanisius, 1995, hlm. 98.

${ }^{56}$ Jan van Gijssel dan Mark van Hocke, What is rechteorie? Terjemahan B. Arif Sidharta, Bandung: Laboratoriun Fakultas Hukum, Universitas Katolik Parahiyangan, 2001, hlm. 110. Lihat juga Abdul Hakim Garuda Nusantara yang mengatakan Pancasila merupakan ideologi hukum nasional karena Pancasila adalah sistem nilai-nilai, cita-cita yang harus diterjemahkan ke dalam produk-produk hukum. I Dewa Gede Atmadja, Ilmu Negara, Sejarah, Konsep Negara dan Kajian Kenegaraan, Malang: Setara Press, 2012, hlm. 61.

${ }^{57}$ A.Gunawan Sutardja, Hak-hak Asasi Manusia Berdasarkan Ideologi Pancasila, Yogyakarta: Kanisius, 1993, hlm. 166.
Nilai hukum ketiga dari Pembukaan UUD 1945 adalah nilai persatuan sebagai termuat pada frasa "Persatuan Indonesia". Frasa ini menjelaskan manusia sebagai makhluk sosial. Nilai ini mengungkapkan tentang kemauan hidup bersama dari individu manusia. Ibnu Khaldun menerangkan negara atau organisasi masyarakat adalah suatu kemestian bagi jenis manusia. ${ }^{58}$ Pemerintah atau negara diciptakan masyarakat agar manusia dapat menikmati hak-hak kodrati mereka. ${ }^{59}$

Dalam kehidupan kelompok kehidupan individu manusia menjadi sempurna, karena melalui kelompok itulah manusia melakukan hubungan atau interaksi satu sama lainnya demi eksistensi dan keberadaan dirinya. Fuller menerangkan interaksi manusia memberikan tujuan kepada hukum dan bahwa idealnya hukum di mana-mana semestinya termanifestasi sebagai kerja kolaboratif yang muncul dari pandangan bernalar tentang urusan manusia. ${ }^{60}$ Tindakan manusia dapat dikelompokkan dalam dua bentuk, yaitu : tindakan manusiawi (actus humanus) dan tindakan manusia (actus hominis) ${ }^{61}$. Kedua bentuk tindakan tersebut berhubungan dengan kebebasan manusia dalam kehidupan masyarakat. Tindakan manusia (actus hominis) nyaris tidak terkait nilai. Ia merupakan tindakan alamiah sematamata yang tidak memiliki makna, berbeda dengan tindakan manusiawi (actus humanus) yang mengandung nuansa nilai, di sini ada nuansa evaluasi dari tindakan bebas manusia.

Manusia melakukan tindakan manusiawi berhubungan dengan pilihan. Dalam kajian ilmu sosial, pilihanlah yang harus menjadi titik tolak dalam melahirkan pola tingkah laku manusia

\footnotetext{
${ }^{58}$ Osman Raliby, Ibnu Khaldun Tentang Masyarakat dan Negara, Jakarta: Bulan Bintang, 1978, hlm. 139,

${ }^{59}$ Goorge Clark dan Kathleen Hug (ed), Hak Asasi Manusia Sebuah Pengantar, terjemahan Th.Hermaya, Jakarta: Pustaka Sinar Harapan, 1998, hlm. 4.

${ }^{60}$ Wener Menski, op.cit., hlm. 226.

${ }^{61}$ Theo Huijbers, op.cit., hlm. 53.
} 
dan perkembangannya. Pilihan tidak ada pada manusia jika manusia tidak memiliki kebebasan ${ }^{62}$. Manusia itu harus memiliki kebebasan untuk melakukan tindakan ${ }^{63}$. Dalam istilah sederhana kebebasan berarti, manusia bebas untuk mengatur hubungan mereka, dan mampu mengatur hubungan mereka, berperilaku berdasarkan kehendan mereka sendiri, dan bertanggungjawab atas tindakan yang dilakukannya ${ }^{64}$. Marquis d'Argeson mengatakan tiap orang bebas secara sempurna berbuat apapun, tidak menyakiti orang lain. Itu adalah batasan yang tidak berubah. ${ }^{65}$ Pada titik itulah tindakan manusiawi (actus humanus) sebagai suatu nilai, ia mengandung penilaian atas tindakan manusia. Di sini manusia harus dihormati dan tanpa memandang ras, jenis kelamin, suku, bangsa, warna kulit dan agama. Penilian itu diperlukan dalam tatanan kehidupan manusia dari situ hukum menampakkan dirinya. Aristoteles mengingatkan kita, ubi societas ibi ius, tidak ada hukum tanpa ada masyarakat. Masyarakat adalah prasyarat lahirnya hukum manusia. Di sini kekuasaan hukum menggantikan dominasi atas manusia. ${ }^{66}$

Nilai hukum keempat adalah musyawarah sebagaimana termuat pada frasa "Kerakyatan yang dipimpin

${ }^{62}$ Tom R. Burns dan Philippe De Ville, Manusia, Keputusan, Masyarakat, Teori Dinamika Antara Aktor dan Sistem Untuk Ilmuwan Sosial, terjemahan Soewono Hadisoemarto, Jakarta: Pradnya Paramita, 2001, hlm. 17.

${ }^{63}$ John Stuart Mill, On Liberty and Other Essays, New York: Oxport Univerity Press, 1998, hlm. 84.

${ }^{64}$ T.S.N. Sastry, Intruduction to Human Rights and Duties, Pune: University pf Pune Press, 2011, hlm. 4.

${ }^{65}$ Jean Jacques Rousseau, The Social Contract, terjemahan Sumardjo, Jakarta: Erlangga, 1986, h. 120. Terhadap pernyataan ini Rousseau berkomentar "Saya kadang kala tidak dapat menyangkal pada diri saya sendiri akan kesenangan mengutip naskah ini, meskipun ia tidak dikenal umum, dengan maksud berbuat hormat terhadap seseorang yang agung dan terhormat, bahkan dalam kependetaan, melindungi hati warga negara yang setia, dan angan-angan yang adil serta menyegarkan terhadap pemerintah dan negaranya".

${ }^{66}$ Raymond Aron, Kebebasan dan Martabat Manusia, terjemahan Rahayu S.Hidayat, dkk, Jakarta: Yayasan Obor, 1993, hlm, 83.

\begin{tabular}{c|c|c}
84 & IUS & Kajian Hukum dan Keadilan
\end{tabular} oleh hikmat, kebijaksanaan dalam permusjawaratan/ perwakilan". Frasa ini berhubungan dengan proses menemukan kebenaran yang berlaku dalam kehidupan bersama. Kebenaran itu sendiri adalah tujuan bukan alat.

Musyawarah sebagai proses menemukan kebenaran bukanlah bentuk kompromi, tetapi semua individu bersama-sama mencari, menyepakati dan menyetujui di dalamnya terkandung nuansa batiniah dalam memaknai, menggapai dan mewujudkan nilai kebenaran suci tunggal dari banyaknya kebenaran-kebenaran yang dianut berdasarkan pandangan-pandangan individu yang diwakili oleh wakilnya untuk menyuarakannya ${ }^{67}$. Semua pihak mengarahkan kepada kebenaran, dan kebenaran itu milik kebenaran itu sendiri. Dalam musyawarah tidak didasarkan pada dominasi antara satu pihak dengan pihak yang lain. Dominasi terjadi manakala suara terbanyak menindas suara minoritas atau sebaliknya. Dominasi itu pada hakekatnya adalah suatu paksaan terselubung sebagai bentuk kekerasan tidak langsung.

Kebenaran adalah tujuan hakiki hidup manusia. Ia tidak hanya monopoli nilai hukum tetapi juga nilai politik, keduanya bertemu pada satu titik yaitu apa yang disebut demokrasi. Nilai politik dan hukum dalam demokrasi tidak dapat dipisahkan secara hitam putih. Contoh klasik dapat dilihat dari sidang Socrates pada masyarakat Yunani Kuno yang didakwa merusak keyakinan masyarakat. Ia disidangkan dihadapan 502 hakim dengan beragam pfofesi kehidupan. Sokrates membantah tuduhan dari penuduhnya. Ia ikrarkan bahwa dirinya merupakan figur yang cukup baik dan menapak petunjuk yang benar sesuai dengan kehedak Tuhan, dan tidak pernah mengharapkan imbalan materi dari profesi yang dilakukannya. Seluruh hakim-hakim segera mengadakan

${ }^{67}$ Djon Pakan, Kembali Kejati Diri Bangsa Indonesia, Jakarta: Milenium Publisher, 2002, hlm. 133. 
sidang. Hasilnya, 281 hakim berpihak kepada penuduh, sedangkan 221 orang berpihak pada Socrates. Akhirnya suara terbanyak menyatakan Socrates bersalah dan ia divonis hukuman mati. Atas hukuman mati tersebut isterinya bertanya "apakah para hakim yang membunuh tuan itu pada pihak zalim dan melampui batas?" Socrates menjawab dengan landai dan penuh kearifan "apakah engkau rela jika mereka dalam pihak yang benar dalam melenyapkanku?".

Ketika pelaksanaan hukuman tiba, menurut undang-undang, ia berhak untuk memilih siksaan yang dianggap ringan dan hal itu ditawarkan kepadanya. Ternyata ia menolak mentah-mentah tawaran itu, sikap itu merupakan pengakuan bahwa dirinya pada pihak yang salah. Ia tidak mau mengakui dosa yang tidak pernah dilakukannya. Malah mengatakan bahwa dirinya lebih layak untuk digaji sebagai imbalan atas jasa dalam membenahi problema publik. Dengan penuh kemantapan ia meraih gelas beracun. Ia tenggak gelas itu hingga menemui ajalnya. Ia pun mati dalam alam demokrastis ....ironis memang! ${ }^{68}$ Ternyata pada kemudian hari, apa yang dinyatakan Socrates terbukti benar, pendapatnya diikuti dan dijadikan rujukan.

Nilai hukum yang kelima adalah keadilan sebagaimana termuat pada frasa "Keadilan Sosial bagi seluruh Rakyat Indonesia". Dalam pembukaan UUD 1945 terdapat 5 kata adil yaitu peri keadilan, seadil-adilnya, adi dan makmur, keadilan sosial, adil dan beradab. Ini menandakan adil sebagai nilai yang penting dan tujuan akhir dari hukum. Ia sebagai dasar evalusi tindakan manusia dan penguasa negara. Keadilan isi terdalam dari hukum. keadilan itu berhubungan dengan kehidupan kemasyarakatan. Dalam hubungan

${ }^{68}$ Taufiq At-Thawil, Pertarungan Agama \& Filsafat, diterjemahkan dari, An-Niza' Baina Ad-Diin Wa Al-Falsafah Daar Mashri li At-Thiba'ah, Maktabah Mashri, 1954, Jatisari, Jawa Timur : Al Furqon, 2013. hlm. 6970. kemasyarakatan keharusan berlaku adil dimulai dari diri sendiri, keluarga dan masyarakat.

Keadilan sangat erat hubungannya dengan menilai keberadaan manusia dalam hubungan sesamanya. Dia adalah suatu konsep yang relevan dengan hubungan antar manusia, dia harus dibahas terutama dalam konteks yang sosial sifatnya. Ciri khas keadilan di antara kebajikankebajikan yang lain, menurut Thomas Aquinas, adalah mengatur manusia dalam hubungannya dengan sesasamanya. Keadilan mengandung keseimbangan ekualitas tertentu sesuai dengan sebutan yang setara, yang secara umum dikatakan sesuatu yang cocok dengan yang lain jika kedua-duanya sebanding ${ }^{69}$. Keadilan berarti keseimbangan atau moderasi ${ }^{70}$.

Nilai keadilan sebagai nilai hukum bagi bangsa Indonesia berhubungan dengan hak-hak manusia terhadap diri manusia dan kebutuhan hidup manusia dan itu semua berhubungan dengan bangunan peradaban bangsa Indonesia. Syarat pertama peradaban adalah keadilan dianut oleh semua kitab hukum sejak Hamurabi demikian Freud mengatakan ${ }^{71}$.

Nilai keadilan sebagai nilai hukum yang termuat frasa "Keadilan Sosial Bagi Seluruh Rakyat Indonesia" sebagai norma pokok yang harus menjadi kiblat bagi setiap rezim politik yang memegang tampuk kekuasaan di bawah konstitusi. Norma itu bermakna ke dua arah. Ke arah positif, adalah kewajiban utama siapapun yang memegang kekuasaan negara untuk mengerahkan kemampuan dan seluruh langkah kebijakannya untuk mewujudkan keadilan sosial; ke arah negatif adalah kewajiban utama siapapun yang memegang kekuasaan

\footnotetext{
${ }^{69}$ E.Somarsono, Etika \& Hukum Relevansi Teori Hukum Kodrat Thomas Aquinas, Yogyakarta: Kanisius, 2002, hlm. 181.

${ }^{70}$ Juhaya S.Praja, Filsafat Hukum Islam, Bandung: LPPM Universitas Islam Bandung, 1995, hlm. 72.

${ }^{71}$ Virgina Adams dan Para Editor Pustaka Time-life, Kejahatan, terjemahan Suwargon Wirono, Jakarta: Tira Pustaka, 1987, hlm. 138.
} 
negara untuk mencegah tumbuh apalagi berkembangnya ketidakadilan ${ }^{72}$. Dari penjelasan ini dapat dipahami bahwa keadilan terkandung di dalamnya dasar kelima negara Indonesia mengandung dua bentuk keadilan yaitu keadilan prosedur dan keadilan substansial, sebagaimana Mill menerangkan keadilan substansial bukan hanya berisi apa yang benar untuk dilakukan atau tidak benar untuk dilakukan, namun juga sesuatu yang memperbolehkan orang lain mengklaim dari kita sesuatu sebagai hak moralnya. Sebagaimana terlihat dari keadilan komutativa dan keadilan distibutiva seperti yang dikemukakan Aristoteles. ${ }^{73}$

\section{SIMPULAN}

Pembukaan UUD 1945 sebagai pembukaan konstitusi negara Indonesia mengandung nilai-nilai dalam menyelenggara kekuasaan negara. Ia mengandung nilai politik sebagai nilai instrumental dan nilai hukum sebagai nilai instrinsik yang menjadi motivasi tindakan bagi penyelenggaraan kekuasaan negara.

Nilai politik yang terkandung di dalam Pembukaan UUD 1945 adalah nilai kebebasan, perdamaian dan keadilan. Nilai hukum yang terkandung di dalam pembukaan UUD 1945 adalah nilai religius, kemanusiaan, persatuan, musyawarah dan keadilan sebagaimana yang termuat pada lima dasar negara Indonesia. Dalam kajian filsafat hukum nilai-nilai tersebut berhubungan dengan otonologi hukum, efistimologi hukum dan aksiologi hukum. Inti nilai-nilai hukum dan politik dalam hukum Pembukaan UUD 1945 pada hakekatnya adalah cita-cita hidup bersama bagaimana memperlakukan manusia sebagai manusia.

Beranjak dari tujuan hakiki dari nilai politik dan hukum yang termauat di

\footnotetext{
${ }^{72}$ Bur Rasuanto, Keadilan Sosial Pandangan Deontol ogis Rawls dan Habermas Dua Teori Filsafat Politik Modern, Jakarta: Gramedia Pustaka Utama, 2005, hlm. 200.

${ }^{73}$ Karen Leback, op.cit., hlm. 21.
}

dalam Pembukaan UUD 1945, maka bagi penyelenggaran kekuasaan politik dan hukum hendaknya dipersyaratkan manusia yang teruji secara moral dan intelektualnya. Dalam mengelola kehidupan manusia kepintaran saja tidak cukup tanpa tanpa diiringi moral yang mumpuni. Bagi pemegang kekuasaan negara hendaknya dipegang oleh orangorang yang memiliki karakter kenegarawan yang memahami manusia sebagai makhluk religius, sosial dan posesif.

\section{DAFTAR PUSTAKA}

\section{Buku}

A.B. Kusuma, 2004, Lahirnya UndangUndang Dasar 1945 Memuat Salinan Dokumen Otentik Badan Oentoek Menyelidiki Oesaha2 Persiapan Kemerdekaan, Jakarta: Fakultas Hukum Universitas Indonesia.

Ade Armanto (ed), 2001, Ensiklopedi Islam Untuk Pelajar, Jakarta: Ichtiar Van Hoeve Adnan Buyung Nasution, 1995, Aspirasi Pemerintahan Konstitusional di Indonesia, terjemahan Sylvia Tiwon, Jakarta: Pustaka Utama Grafiti.

A.Gunawan Sutardja, 1993, Hak-hak Asasi Manusia Berdasarkan Ideologi Pancasila, Yogyakarta: Kanisius.

'Alija 'Ali Izetbegovic, 1992, Membangun Jalan Tengah Islam antara Timur dan Barat, terjemahan Nurul Agustina, Farid Gaban, Bandung: Mizan.

Amril M. 2002, Etika Islam Telaah Pemikiran Filsafat Moral Raqhib Al-Isfahani, Pekan Baru: LSFK2P bekerjasama dengan Yogyakarta: Pustaka Pelajar.

Anwar Abbas, 2008, Bung Hatta \& Ekonomi Islam, Pergulaan 
Zulfirman \& Ridho Syahputra Manurung |Pembukaan Uud 1945: Analisis Nilai Politik Dan Nilai......

Menangkap Makna Keadilan dan Kesejahteraan, Jakarta: Kerjasama LP3M, Fakultas Hukum Universitas Muhamadyah dan Multi Pressindo.

Bernard L.Tanya, et.al, 2013, Teori Hukum Strategi Tertib Manusia Lintas Ruang dan Generasi, Yogyakarta: Genta Publishing.

Bertand Russel, 1953, Kekuasaan dan Individu, terjemahan Kamaruzzaman, Jakarta: Yayasan Pembangunan.

Budiono Kusumohamidjojo, 2004, Filsafat Hukum, Problematik Ketertiban yang Adil, Jakarta: Grasindo.

Bur Rasuanto, 2005, Keadilan Sosial Pandangan Deontologis Rawls dan Habermas Dua Teori Filsafat Politik Modern, Jakarta: Gramedia Pustaka Utama.

Carl Joachim Friedrich, 2004, Filsafat Hukum Persepektif Historis, terjemahan Raisul Muttaqien, Bandung: Nuasa bekerjasama dengan Nusamedia,.

Charles F. Andrain, 1992, Kehidupan Politik dan Perubahan Sosial, terjemahan Luqman Hakim, Yogyakarta: Tiara Wacana.

Craig Biddle, 2011, “Any Rand's Theory of Rights : The Moral Foundation of a Free Society", The Objective Standard, Glen Allen Press, Vol. 6, No. 3, h. 66 .

Dadang Juliantra, 1999, Jalan Kemanusiaan, Panduan Untuk Memperkuat Hak Asasi Manusia, Yogyakarta: Lapera Pustaka Utama.

Darji Darmodiharjo dan Shidarta, 2002, Pokok-Pokok Filsafat Hukum Apa dan Bagaimana Filsafat Hukum Indonesia, Jakarta: Gramedia
Pustaka Utama.

Djon Pakan, 2002, Kembali Kejati Diri Bangsa Indonesia, Jakarta: Milenium Publisher.

Evan J. Criddle, Evan Fox-Decent, 2012, Human Rights, Emergencies, and the Rule of Law, Human Rights Quarterly, The Johns Hopkins University Press, Vol. 34, No. 1.

E.Somarsono, 2002, Etika \& Hukum Relevansi Teori Hukum Kodrat Thomas Aquinas, Yogyakarta: Kanisius.

Francis Fukuyama, 2005, Memperkuat Negara Tata Pemerintahan dan Tata Dunia abad 21, terjemahan A. Zaim Rofiqi, Jakarta: Gramedia Pustaka Utama.

Goorge Clark dan Kathleen Hug (ed), 1998, Hak Asasi Manusia Sebuah Pengantar, terjemahan Th.Hermaya, Jakarta: Pustaka Sinar Harapan.

Hesti Armiwulan Sochmawardiah, 2013, Diskriminasi Rasial Dalam Hukum HAM, Studi Diskriminasi Terhadap Ethnis Tionghoa, Yogyakarta : Genta Publishing.

I Dewa Gede Atmadja, 2012, Ilmu Negara, Sejarah, Konsep Negara dan Kajian Kenegaraan, Malang: Setara Press.

Jan van Gijssel dan Mark van Hocke, 2001, What is rechteorie? Terjemahan B. Arif Sidharta, Bandung: Laboratoriun Fakultas Hukum, Universitas Katolik Parahiyangan.

Jean Jacques Rousseau, 1986, The Social Contract, terjemahan Sumardjo, Jakarta: Erlangga.

Jimly Asshiddiqie, 2004, Konstitusi \&Konstitusionalisme Indonesia, Jakarta: Mahkamah Konstitusi RI berkerjasama dengan Pusat Studi 
Hukum Tata Negara FH Univ. Indonesia.

John Stuart Mill, 1998, On Liberty and Other Essays, New York : Oxport Univerity Press.

Juhaya S.Praja, 1995, Filsafat Hukum Islam, Bandung: LPPM Universitas Islam Bandung.

Karen Leback, 2015, Teori-Teori Keadilan, terjemahan Yudi Santoso, Bandung: Nusa Media.

Miriam Budiardjo, 2013, Dasar-Dasar Ilmu Politik, Jakarta: Gramedia Pustaka Utama.

Miriam Budiarjo, 2013, Dasar-Dasar Ilmu Politik, Jakarta: Gramedia Pustaka Utama.

MPR, 2012, Panduan Pemasyarakatan Undang-Undang Dsar Negera Republik Indonesia Tahun 1945 Dan Ketetapan Majelis Permusyawaratan Rakyat Republik Indonesia, Jakarta: Sekretariat Jendral MPR RI.

Osman Raliby, 1978k, Ibnu Khaldun Tentang Masyarakat dan Negara, Jakarta: Bulan Bintang.

PT Cipta Adi Pustaka, 1990, Ensiklopedi Nasional Indonesia, jilid 13, Jakarta: Cipta Adi Pustaka.

Raymond Aron, 1993, Kebebasan dan Martabat Manusia, terjemahan Rahayu S.Hidayat, dkk, Jakarta: Yayasan Obor.

Repulika.co.id, Pancasila, Sukarno, Piagam Jakarta, dan Debat Dasar Negara, 21 Sya'ban 1438 H/17 May 2017, tanggal 17 May 2017.

Risieri Frondizi, 2001, Pengantar Filsafat Nilai, terjemahan Cuk Ananta Wijaya, Yogyakarta: Pustaka Pelajar.

Shalom H. Schwartz, 2009, Basic Human
Values, Paper : Comparation Seminar on the Quality and Comparability of Measures for Constructs in Comparative Research: Methods and Applications, Bolzano (Bozen), Italy, June 10-13,

Sukarna, 1981, Kekuasaan, Kediktatoran dan Demokrasi, Bandung: Alumni.

S. Silalahi, 2001, Dasar-dasar Indonesia Merdeka versi Para Pendiri Negara, Jakarta: Gramedia Pustaka Utama.

Taufiq At-Thawil, 2013, Pertarungan Agama \& Filsafat, diterjemahkan dari, An-Niza' Baina Ad-Diin Wa Al-Falsafah Daar Mashri li At-Thiba'ah, Maktabah Mashri, 1954, Jatisari, Jawa Timur : Al Furqon.

Theo Huijbers, 1995, Filsafat Hukum, Yogyakarta: Kanisius.

Tom R. Burns dan Philippe De Ville, 2001, Manusia, Keputusan, Masyarakat, Teori Dinamika Antara Aktor dan Sistem Untuk Ilmuwan Sosial, terjemahan Soewono Hadisoemarto, Jakarta: Pradnya Paramita.

T.S.N. Sastry, 2011, Intruduction to Human Rights and Duties, Pune: University of Pune Press.

Virgina Adams dan Para Editor Pustaka Time-life, 1987, Kejahatan, terjemahan Suwargon Wirono, Jakarta: Tira Pustaka.

Werner Menski, 2012, Perbandingan Hukum dalam Konteks Global Sistem Hukum Eropa, Asia dan Afrika, terjemahan M.Kozhim, Bandung: Nusa Media.

Wawan Tunggul Alam (ed), 2001, Bung Karno Menggali Pancasila, 
Zulfirman \& Ridho Syahputra Manurung |Pembukaan Uud 1945: Analisis Nilai Politik Dan Nilai.......

Kumpulan Pidato, Jakarta:

Gramedia Pustaka Utama.

W. Poespoprodjo, 1986, Filsafat Moral, Kesusilaan dan Teori dan Praktek, Bandung: Remaja Karya.

Ziauddin Sardar dan Marryl Way Davies, 1992, Wajah Islam, Bandung: Mizan.

\section{Undang-Undang}

Undang-Undang Dasar Negara Republik Indonesia Tahun 1945

\section{Internet.}

http://www.humanrights.com/whatare-human-rights/brief-history/ syrus-cylinder.html, diunduh t13 April 2017. 